\title{
Implications of Auditor Characteristics and Directors' and Officers' Liability Insurance for Going-Concern Audit Opinions: Evidence from Taiwan
}

\author{
Hsiang-Tsai Chiang ${ }^{1}$, Shu-Lin Lin $^{2} \&$ Li-Jen $\mathrm{He}^{3}$ \\ ${ }^{1}$ Department of Accounting, Feng Chia University, Taiwan \\ ${ }^{2}$ Department of International Business Management, Hsiuping University of Science and Technology, Taiwan \\ ${ }^{3}$ Department of Accounting and Information Systems, Asia University, Taiwan \\ Correspondence: Shu-Lin Lin, Department of International Business Management, Hsiuping University of \\ Science and Technology, Taiwan. E-mail: sue@ hust.edu.tw
}

Received: February 23, 2015

Accepted: March 24, 2015

Online Published: April 25, 2015

doi:10.5539/ibr.v8n5p130

URL: http://dx.doi.org/10.5539/ibr.v8n5p130

\begin{abstract}
This study explores the association among auditor characteristics, directors' and officers' (D\&O) insurance, and auditors' intention to issue going-concern opinions. For the insured decision, the results show that clients of auditors with greater market shares, better reputation (Big 4), and those that had been punished had higher D\&O insurance coverage. For the results of audit opinion, the results show that the industry-specific experience of auditors and audit firm size are significantly negatively associated with the issuing of going-concern opinion. It is consistent with our expectations that since Big 4 auditors may share more litigation risk and possess more loss coverage of audit failure of $\mathrm{D} \& \mathrm{O}$ insurance, the effects of $\mathrm{D} \& \mathrm{O}$ insurance on auditors' intention of issuing going-concern opinions are more significant for Big 4 auditors.
\end{abstract}

Keywords: corporate governance, directors' and officers' liability insurance, going-concern opinion, Big 4 firm, industry specialist

\section{Introduction}

This study explores the association among company D\&O insurance, auditor characteristics and audit opinion. Since Jensen and Meckling (1976) documented the agency problems raised from the separation of principle and agency, issues of corporate ownership and control is widely documented since this separation creates a need for expenses that align the goals of owners and managers. Among stakeholders, officers, board of directors, and auditors are demonstrated to play most important roles in governance mechanisms. In addition, since all them three are required to joint and several liabilities with companies, to understand the possible association between director and officer insurance (here after, D\&O insurance) and auditors' behavior should be interesting and important. While prior studies have widely discussed the association between D\&O insurance and corporate governance (e.g., Holderness, 1990; Core, 1997; O'Sullivan, 2002; Redington, 2005), rare of them has explored this issue by focusing on the aspect of auditor as we know. Therefore, this study explores this issue by examining the association among company D\&O insurance, auditor characteristics and audit opinion.

Most literature about corporate boards and governance structures provide evidence that the board exists to ensure managerial action consistent with the goals of corporate owners; however, disagreement exists about how that duty is exercised, and the rights of shareholders and their board agents (Barrese \& Scordis, 2006). For instance, while board members are expected to be served the responsibility to diminish the agency problem between owners and managers, the system of determining board membership may be designed to pre-dispose directors toward managers. Besides, while board members may have the decision rights, managers are the executors of corporate as a matter of fact. These reasons provide possible risk to the identification of the duties of the board and officers, consequently, to the insurance provided for director and officer liabilities.

Early D\&O insurance can be traced back to the 1960s when the board of directors and management faced increasingly higher risk accompanied with changes in the interpretation of the securities laws that increase their responsibility. At first, D\&O insurance only covered boards of directors and management. However, recent 
financial distress and a large number of lawsuits, such as Enron and WorldCom events, raise the demand for D\&O insurance for the whole company. Therefore, nowadays, D\&O insurance covers not only directors and officers but also company entities. Chen and $\mathrm{Li}$ (2010) indicate that while it has become a trend that investors sue the firms and their board members and managers when the investments does not get good return, D\&O insurance has become a primary tool used to reduce company risk and operation failure problems in today's society.

Prior studies suggest that corporate D\&O insurance may be demanded for reducing a company's litigation or business risk (e.g., Core, 1997; O'Sullivan, 2002; Cao \& Narayanamoorthy, 2014); ownership structure (Mayers \& Smith, 1990); and the quality of corporate governance (e.g., Core, 2000; Chung \& Wynn, 2008; Chamlers, Dann, \& Harford, 2002). However, while D\&O insurance provides coverage for possible loss from business failure and litigation, $\mathrm{D} \& \mathrm{O}$ insurance can induce moral hazard on the part of the directors and management, such as managers' opportunistic behavior (Chamlers et al., 2002; Boyer, 2003). For instance, Core (2000) indicated that company $\mathrm{D} \& \mathrm{O}$ premiums are positively associated with excess CEO compensation. Besides, Chalmers et al. (2002) (Note 1) suggest that the purchase of D\&O insurance is likely to induce managers' opportunistic behavior, and companies with D\&O insurance in conjunction with an IPO are likely to have lower stock price performance three years after the transaction. Therefore, although $\mathrm{D} \& \mathrm{O}$ insurance provides some economic protection for corporations, their directors and their officers, it may also obtain some negative impacts from the market. Lin, Officer and Zou (2011) provide evidence that acquiring firms with greater D\&O insurance experience lower announcement-period abnormal returns in a merger and acquisition deal.

Besides to directors and officers, auditors are expected to provide the other insurance role for investors as well. Dye (1993) indicated that auditors with "deep pockets" could function as insurers because they are prone to claims from investors when companies file for bankruptcy. From 2004 to 2012, 36 listed companies, as well as their boards of directors and management, were sued by investor protection organizations according to the Taiwan Investment Protecting Association (Note 2). Among these 36 cases, 34 of them sued auditors as codefendants. For instance, for the "REBAR" event in 2007, which is one of the most famous cases of financial fraud in Taiwan; the total claim for loss compensation was 33 billion, while KPMG and Deloitte were compensated 102 million and 72 million, respectively.

Since D\&O insurance may partially cover the litigation risk and loss of audit failure for auditors, will it release auditors from stringent opinion intentions as a result? Moreover, will the impact of D\&O insurance on auditors' reporting intention (if any) be different among types of auditors? While prior studies have widely discuss D\&O insurance from the perspective of corporate governance (e.g., Core, 1997; Holderness, 1990; O'Sullivan, 2002) and the demand for D\&O insurance (e.g., Hoyt \& Khang, 2000; Redington, 2005; Chen \& Pang, 2008), rare of them discuss $\mathrm{D} \& \mathrm{O}$ insurance from the aspect of auditors' characteristics and reporting behavior. However, auditors share the litigation risk with directors and officers of their client companies as a matter of fact. Accordingly, this study would like to fill this gap by investigating the association among company D\&O insurance, auditor characteristics and audit opinion.

For the insured decision, the results show that clients of auditors with greater market shares, better reputations (Big 4), and those that had been punished higher D\&O insurance coverage. Moreover, we find that the auditor's industrial experience and the indication variable of Big 4 firms are significantly negatively associated with the issuing of going-concern opinion, while the negative association between the indicator of auditor specialization and issuing of going-concern opinion are not significant. In other words, the results suggest that compared to auditors' industry experience and audit firm size, auditor specialization possesses less influence on issuing going-concern opinions of auditors. In addition, the results show that the interaction variables of the indication variable of Big 4 firms and the indication variable of $\mathrm{D} \& \mathrm{O}$ insurance are significantly negatively associated with the issuing of going-concern opinion. That is, since Big 4 auditors have higher cost of audit failure, and $\mathrm{D} \& \mathrm{O}$ insurance may partially cover the litigation risk and loss of audit failure, the effects of D\&O insurance on auditors' intension of issuing going-concern opinions are more significant for Big 4 auditors. Furthermore, the results of this study also show that, compared to those with $\mathrm{D} \& \mathrm{O}$ insurance, companies without $\mathrm{D} \& \mathrm{O}$ insurance had better corporate governance mechanisms. The Monitoring Hypothesis suggests that firms with weak corporate governance have a greater incentive to purchase D\&O insurance (Chen, 2013). Taking the governance strategies as a whole, companies have the following three approaches for obtaining better corporate governance effect: strengthen corporate governance mechanisms, buy D\&O insurance, or engage with higher audit-quality auditors. However, all the approaches have cost, probably very high cost, so the choices for a better corporate governance effect must be made under cost consideration. For instance, compared to companies with poorer corporate governance, companies with better corporate governance may have lower demand for $\mathrm{D} \& \mathrm{O}$ insurance, 
since they have invested more in strengthening corporate governance mechanisms and have received a positive response from investors. On the other hand, in comparison with companies with better corporate governance, companies with poorer corporate governance may have higher demand for D\&O insurance and higher quality auditors, since having such allows them to gain a positive response from capital market. Therefore, there is a complementary relationship between purchasing D\&O insurance, strengthening corporate governance mechanisms, and engaging with high-quality auditors based on the cost control for overall corporate governance investment.

This study contributes to audit demand related studies by examining the influence of audit characteristics on client companies' D\&O insurance decisions to demonstrate the auditors role on companies' decision making. Furthermore, by examining the association among D\&O insurance, audit characteristics, and D\&O insurance, this study provide evidence of the impacts of D\&O insurance on auditors' intentions to issue going-concern opinions while prior studies have rare document the $\mathrm{D} \& \mathrm{O}$ insurance issues from the aspect of audit quality.

The remainder of this paper is organized as follows. The subsequent section presents a review of related studies and our hypotheses. Section 3 details the research design and sample selection. Section 4 discusses the empirical results, and the conclusion is offered in Section 5.

\section{Related Studies and Hypotheses Development}

\subsection{Auditor Characteristics and D\&O Insurance}

From the viewpoint of Risk Avoidance Theory, auditors can either resign audit engagements or increase audit fees for clients with higher risk to reduce possible litigation risk (Johnston \& Bedard, 2004; Seetharaman, Gul, \& Lynn, 2002). However, from the viewpoint of audit client portfolio management, clients with higher risk may be acceptable. For instance, Reynolds, Deis, and Francis (2004) suggest that audit firms do not simply reject all clients that are assessed with greater litigation risk, but rather discontinue clients who are less attractive. From the viewpoint of the auditor's insurance role, which is demonstrated as one of the main demands of an audit (DeAngelo, 1981), companies with D\&O insurance may reduce the possibility and financial losses of business failure (since it is demonstrated to be a good external governance mechanism). Therefore, when an auditor engaged with a company that purchased D\&O insurance, it may reduce the litigation risk and loss of audit failure for auditors based on the good governance effect of $\mathrm{D} \& \mathrm{O}$ for the company. Moreover, prior studies suggest that since high-quality auditors are expected to provide better audit quality, they will experience severe punishment for audit failure (DeAngelo, 1981a, 1981b; Krishnan, 2003). For instance, DeAngelo (1981) demonstrate that, in order to gain more reputational and less legal risk, large audit firms have higher incentive to provide better audits Studies of internal control also suggested that higher-quality auditors have greater litigation risk and therefore have greater incentive to disclose internal control weaknesses to avoid litigation (Ashbaugh-Skaife, Collins, \& Kinny, 2007; Rose-Green, Huang, \& Lee, 2011). In addition, Chen (2013) suggests that the D\&O insurance may release a positive signal effect for the insured firms. Therefore, since companies may ask for advising from auditors when making important business strategies (Louis, 2005); we consider that, rather than reject high-risk clients, auditors may reduce the litigation risk by inducing these clients to enhance their governance mechanisms, such as through purchasing D\&O insurance.

In other words, we hypothesize that, compared to auditors with less reputation cost and litigation risk, auditors with higher reputation cost and litigation risk will be more likely to suggest that their client purchase D\&O insurance. Furthermore, Casterella, Jensen, and Knechel (2010) indicate that the characteristics of audit firms can lead to different litigation risks and suggest that audit firms with larger size, higher growth rate, and experienced sanction have higher litigation risk. For the reputation cost of auditors, compared to non-specialist auditors and auditors with smaller size, less market share, or less audit experience, specialist auditors have invested greater resources in their clients, and are likely to experience greater losses from the audit failure. However, from the perspective of corporate governance, since the specialization and experience of auditors may increase audit quality, they may reduce the D\&O insurance cost as a result. Consequently, rather than expect the directions, we only hypothesize that firm size, industry specialization, market shares, and sanction experience of auditors are associated with the purchase of their clients' D\&O insurance. The hypothesis is proposed as follows:

H1: Auditor characteristics are associated with the D\&O insurance taken out by their clients.

\subsection{Auditor Characteristics, D\&O Insurance, and Audit Opinions}

Since the audit opinion is the final product of audit processes, it is demonstrated to be one of the most important measurements of audit quality (McKeown, Mutchler, \& Hopwood, 1991; Geiger \& Raghunandan, 2002; Jackson, Moldrich, \& Roebuck, 2008) From the viewpoint of corporate governance, prior studies suggested that 
companies with strong corporate governance are more likely to engage high quality auditors (Abbott \& Parker, 2000), are more likely to support the auditor in a going concern opinion decision (Carcello \& Neal, 2000), and are less likely to dismiss an auditor following the going concern opinion (Carcello \& Neal, 2003). Moreover, Goodwin \& Seow (2002) showed that strengthening external governance mechanisms can improve the quality of corporate financial statements, facilitate identifying and preventing operational errors, and causes the inadequacy of specific internal controls to be exposed. Similarly, DeFond and Hung (2004) indicated that a relatively strong external governance mechanism could alter the governance behaviors of a company, thereby affording greater protection for investors. In addition, Wen (2011) suggested that companies with an excessive amount of D\&O insurance yield a lower earnings quality; as a form of external governance, this positively influences the decisions of auditors. Consequently, from the prospection of corporate governance, D\&O insurance should be positively associated with auditors' intention of issuing going-concern opinions.

On the other hand, from the viewpoint of audit failure, prior studies suggest that auditors' intention of issuing going-concern opinions will be influenced by the litigation risk they faced (Carcello \& Palmrose, 1994; Blacconiere \& DeFond, 1997; Khurana \& Raman, 2004). From this perspective, since D\&O insurance may partially cover the litigation risk and loss of audit failure for auditors, it is possible to release auditors from stringent opinion intentions as a result. Consequently, from the perspective of audit failure, D\&O insurance should be negatively associated with auditors' intention of issuing going-concern opinions. Furthermore, while the risk orientation of auditors (Lennox, 1999), the influence of D\&O insurance may be different among auditors' characteristics. Consequently, rather than expect the directions, we only propose that D\&O insurance and auditor characteristics are associated with the intention of auditors to issue going-concern opinions to their clients. The hypothesis is proposed as follows:

H2: Auditor characteristics and $\mathrm{D} \& \mathrm{O}$ insurance are associated with going-concern opinions of client companies.

\section{Research Methodology}

\subsection{Research Data and Sample}

We acquired D\&O insurance and financial data for all companies listed in the Taiwan Stock Exchange Corporation and GreTai Security Market. In addition, we obtained data on auditors practicing since 1983 and those sanctioned since 1998, as reported by the Financial Management Committee in the Taiwan Economics Journal (TEJ) database. We also used the TEJ industry classification definitions (Table 1). Among the 4,342 original samples obtained, we observed 3,621 samples after removing observations that were missing financial or audit report data, as well as those that had incomplete data for 3 years.

Table 1 shows that the overall insurance coverage ratio increased from $48.55 \%$ in 2008 to $54 \%$ in 2010 . The banking and securities industries were ranked as the top two industries, followed by the electronics industry, because more than $50 \%$ of all listed companies in Taiwan operate in electronics-related sectors. However, approximately $50 \%$ of all listed companies did not have D\&O insurance. This lack could be attributable to specific requirements associated with cross-border investments (e.g., issuance of depository receipts, complying with local national laws that demand adherence to a higher insurance rate), thereby indicating the necessity for further development of D\&O insurance in Taiwan.

Table 1 . Industry group summary

\begin{tabular}{lccccccccc}
\hline & \multicolumn{3}{c}{2008} & \multicolumn{3}{c}{2009} & \multicolumn{3}{c}{2010} \\
\hline Industry Group & Obs. & Insure No. & Insure Rate (\%) & Obs. & Insure No. & Insure Rate (\%) & Obs. & Insure No. & Insure Rate (\%) \\
Cement & 11 & 4 & 36.36 & 11 & 4 & 36.36 & 11 & 4 & 36.36 \\
Food & 23 & 6 & 26.09 & 23 & 7 & 30.43 & 23 & 7 & 30.43 \\
Plastic & 31 & 14 & 45.16 & 31 & 14 & 45.16 & 31 & 13 & 41.94 \\
Textile & 64 & 5 & 7.81 & 63 & 7 & 11.11 & 62 & 7 & 11.29 \\
Ilectrical machinery & 66 & 20 & 30.30 & 66 & 23 & 34.85 & 67 & 26 & 38.81 \\
Electrical cable & 10 & 1 & 10.00 & 10 & 2 & 20.00 & 10 & 2 & 20.00 \\
IM medical & 74 & 26 & 35.14 & 74 & 29 & 39.19 & 74 & 32 & 43.24 \\
Glass ceramics & 7 & 1 & 14.29 & 7 & 1 & 14.29 & 6 & 1 & 16.67 \\
Paper & 7 & 2 & 28.57 & 7 & 2 & 28.57 & 7 & 2 & 28.57 \\
Steel & 47 & 17 & 36.17 & 47 & 18 & 38.30 & 47 & 19 & 40.43 \\
\hline
\end{tabular}




\begin{tabular}{|c|c|c|c|c|c|c|c|c|c|}
\hline Rubber & 11 & 2 & 18.18 & 11 & 2 & 18.18 & 11 & 3 & 27.27 \\
\hline Automobile & 6 & 1 & 16.67 & 6 & 2 & 33.33 & 6 & 2 & 33.33 \\
\hline Electronics & 664 & 424 & 63.86 & 665 & 446 & 67.07 & 659 & 454 & 68.89 \\
\hline Building materials & 57 & 9 & 15.79 & 57 & 12 & 21.05 & 63 & 18 & 28.57 \\
\hline Shipping & 21 & 7 & 33.33 & 21 & 7 & 33.33 & 21 & 7 & 33.33 \\
\hline Tourism & 13 & 2 & 15.38 & 13 & 2 & 15.38 & 13 & 3 & 23.08 \\
\hline Banking/Insurance & 34 & 20 & 58.82 & 34 & 22 & 64.71 & 34 & 25 & 73.53 \\
\hline Trading & 14 & 3 & 21.43 & 14 & 3 & 21.43 & 15 & 3 & 20.00 \\
\hline Securities/Futures & 10 & 7 & 70.00 & 10 & 7 & 70.00 & 10 & 7 & 70.00 \\
\hline Others & 37 & 15 & 41.03 & 37 & 17 & 46.15 & 37 & 17 & 46.15 \\
\hline Total & 1,207 & 586 & 48.55 & 1,207 & 627 & 51.94 & 1,207 & 652 & 54.01 \\
\hline
\end{tabular}

Resource: TEJ database.

\subsection{Empirical Model}

The insurance amount represents the estimated value of the expected litigation risk of a company; this value increases in conjunction with the anticipated litigation risk. We use Equation (1) to test the association between auditor characteristics and client companies' intentions on purchasing D\&O insurance (for whole sample companies), and use companies with $\mathrm{D} \& \mathrm{O}$ insurance to explore the association between auditor characteristics and insurance amount in Equation (2).

\subsubsection{Auditor Characteristics and D\&O Insurance}

Equations (1) and (2) were employed to determine the effect of auditor characteristics on the D\&O insurance of a client:

$$
\begin{aligned}
D \& O & =\beta_{0}+\beta_{1} \text { Cpa } 1_{-} \text {Age }+\beta_{2} \text { Cpa } 1_{-} \text {Ind }+\beta_{3} C p a 2_{-} \text {Age }+\beta_{4} \text { Cpa } 2_{-} \text {Ind }+\beta_{5} \text { Big } 4 \\
& +\beta_{6} \text { Market }+\beta_{7} \text { Spec }+\beta_{8} \text { Punish }++\beta_{9} C S R+\beta_{10} R \& D+\beta_{11} \text { Bate }+\beta_{12} \text { Crisis } \\
& +\beta_{13} \text { Zscore }+\beta_{14} \text { Loss }+\sum_{i=1}^{n} \beta_{i} \text { Industry }+\varepsilon \\
\text { Ins_Amt } & =\beta_{0}+\beta_{1} \text { Cpa } 1_{-} \text {Age }+\beta_{2} \text { Cpa } 1_{-} \text {Ind }+\beta_{3} \text { Cpa } 2_{-} \text {Age }+\beta_{4} \text { Cpa } 2_{-} \text {Ind }+\beta_{5} \text { Big } 4 \\
& +\beta_{6} \text { Market }+\beta_{7} \text { Spec }+\beta_{8} \text { Punish }++\beta_{9} C S R+\beta_{10} R \& D+\beta_{11} \text { Bate }+\beta_{12} \text { Crisis } \\
& +\beta_{13} \text { Zscore }+\beta_{14} \text { Loss }+\sum_{i=1}^{n} \beta_{i} \text { Industry }+\varepsilon
\end{aligned}
$$

\subsubsection{Auditor Characteristics, D\&O Insurance, and Going-Concern Opinions}

While for healthy firms, the going-concern decision is trivial. The sample used for the analysis of going-concern opinions in this section consist of distressed companies only. Besides, for controlling for the possible self-selection problems, the Heckman two-stage (Heckman, 1979) regression is used to discuss the association among auditor characteristics, D\&O insurance and audit opinion in this study. The models are presented as follows :

The first stage: OLS regression of Business and D\&O insurance

$$
\begin{gathered}
D \& O=\beta_{0}+\beta_{1} C S R+\beta_{2} R \& D+\beta_{3} \text { Bate }+\beta_{4} \text { Crisis }+\beta_{5} \text { Zscore }+\beta_{6} \text { Loss }+\varepsilon \\
\text { Ins_Amt }=\beta_{0}+\beta_{1} C S R+\beta_{2} R \& D+\beta_{3} \text { Bate }+\beta_{4} \text { Crisis }+\beta_{5} \text { Zscore }+\beta_{6} \text { Loss }+\varepsilon
\end{gathered}
$$

The second stage: Logistic regression of D\&O insurance and GC opinion

$$
\begin{aligned}
& \text { Opion_GC }=\beta_{0}+\beta_{1} C p a_{-} \text {Age }+\beta_{2} C p a_{-} \text {Ind }+\beta_{3} \text { Big } 4+\beta_{4} \text { Market }+\beta_{5} \text { Spec }+\beta_{6} \text { Punish } \\
& +\beta_{7} \text { Size }+\beta_{8} D \& O+\beta_{9} \text { Mills }+\sum_{i=1}^{n} \beta_{i} \text { Industry }+\varepsilon \\
& \text { Opion_GC }=\beta_{0}+\beta_{1} C p a \_A g e+\beta_{2} C p a \_ \text {Ind } \beta_{3} B i g+\beta_{4} M \text { arkett } \beta_{5} S p e \notin \beta_{6} \text { Punis } \\
& +\beta_{7} \operatorname{Siz} \beta_{8} \text { Ins } s_{-} \text {m t } \beta_{9} \lambda++\sum_{i=1}^{n} \beta_{i} \text { Indust }+y
\end{aligned}
$$




\subsubsection{Dependent Variables}

$\mathrm{D} \& \mathrm{O}$ insurance $(D \& O)$ : A dummy variable to indicate a company with $\mathrm{D} \& \mathrm{O}$ insurance.

Insured amount (Ins_Amt): The size of D\&O insurance of a company which is measured by nature logarithm of a company's D\&O insured amount.

Going-concern audit opinions (Opion_GC): A dummy variable to indicate a company receives a going-concern opinion from its auditor.

\subsubsection{Independent Variables}

Auditor seniority (Cpa_Age): The seniority of an auditor, which is measured by the years that particular auditor has worked since 1983 (Note 3).

Auditor industry experience (Cpa_Ind): The industry-specific experience of an auditor, which is measured by the years that particular auditor has worked in a specific industry since 1983.

Auditor market share (Market): The market share of an auditor, which is measured by the ratio of the summary of clients' market value of each auditor to the total market value of the listed companies.

Auditor punishment (Punish): A dummy variable to indicate if the leading or concurring auditor of a company has ever been sanctioned since 1998 (Note 4).

Big 4 firm (Big4): A dummy variable to indicate a company was audited by Big 4 audit firm.

Industry specialist $(\mathrm{Spec})$ : A dummy variable to indicate a company was audited by an industry specialist auditor. We applied the company's sales revenue to calculate the industry-specific market share of the auditor (Casterella, Francis, Lewis, \& Walker, 2004; Krishnan, 2003) and classified an auditor as a specialist if the auditor had 33 percent or more market share in an industry (Huang, Liu, Raghunandan, \&Rama, 2007; Rose-Green et al., 2011).

\subsubsection{Control Variables}

The business environment involves uncertainties, such as financial and operational risk, maybe results distress and litigation risk. In this study, we proposed that companies that experienced a financial crisis, a net loss in previous year, and Altman Z score is less than 1.81 to measure financial risks, as well as the expenditure ratio for research and development $(\mathrm{R} \& \mathrm{D})$, social responsibility event, and market bate to measure operational risks. We predict that these variables will have positive correlation with $\mathrm{D} \& \mathrm{O}$ insurance.

CSR (CSR): A dummy variable to indicate a company that experienced negative corporate social responsibility events (Note 5) in previous two years had.

$\mathrm{R} \& \mathrm{D}(R \& D)$ : $\mathrm{R} \& \mathrm{D}$ investment of a company which is measured by the ratio of research and development expenditure to total sales.

Beta (Beta): The systematic risk of a company which is measured by the 12 months' market beta.

Crisis (Crisis): A dummy variable to indicate if a company has ever been classified as a financial crisis company in the TEJ database since 1990.

$\mathrm{Z}$ score (Zscore): A dummy variable to indicate a company with an Altman $\mathrm{Z}$ score less than 1.81 (Asthana, Balsam, \& Krishnan, 2010).

Loss (Loss): A dummy variable to indicate a company reported a net loss in previous year.

Company size (Size): According to Becker, DeFond, Jiambalvo, and Subramanyam (1998), we use the nature logarithm of a company's total assets to measure the size of company. Finally, we include 20 industry indicator variables since Ge and McVay (2005) suggest that there is an association between internal control weaknesses and firm industry. We estimate our regression models with and without the industry variables with qualitatively identical results.

\section{Results}

\subsection{Descriptive Statistical Analysis}

Table 2 presents the descriptive statistics. The mean values of the companies' D\&O insurance $(D \& O)$ and insured amount (Ins_Amt) are 0.52 and 5.21, respectively. The mean of the going-concern opinions (Opion_GC) is 0.02 , which is consistent with the reservations included in the audit opinions.

Regarding the auditor characteristics, the average practice seniority of the leading and concurring auditors are 11.86 (Cpal_Age) and 11.88 (CPa2_Age) years, respectively, whereas the mean values of the industry experience variables are 8.11 (Cpal_Ind) and 7.48 (Cpa2_Ind) years, respectively. This shows that the leading 
auditor possessed greater industry experience. The mean market share among the auditors is $0.5 \%$, indicating that the Taiwanese audit market is highly competitive. The mean values of Big4 and Spec are 0.83 and 0.10, respectively, indicating that the Big 4 firms had audited the majority of listed companies in Taiwan. The mean of Punish was 0.10. Because the majority of punishments imposed on the audit firms in Taiwan applied to individual accountants, the degree of market competition enabled auditors with established reputations to improve their auditing quality. Regarding the control variables, the mean values for $C S R, R \& D$, Bate, Crisis, Zscore, Loss, and company size are $0.12,4.22 \%, 0.91,0.02,0.34,0.35$, and 6.62 , respectively.

Table 2. Descriptive statistics

\begin{tabular}{|c|c|c|c|c|c|}
\hline Variables & Mean & Median & S.D. & Min & Max \\
\hline$D \& O$ & .52 & 1.00 & .50 & .00 & 1.00 \\
\hline Ins_Amt & 5.21 & 5.20 & .47 & 2.06 & 6.82 \\
\hline Opin_GC & .02 & .00 & .15 & .00 & 1.00 \\
\hline Cpa_Age & 15.56 & 15.00 & 5.41 & 1.00 & 28.00 \\
\hline Cpal_Age & 11.86 & 12.00 & 5.94 & 1.00 & 28.00 \\
\hline Cpa2_Age & 11.88 & 12.00 & 6.42 & 1.00 & 28.00 \\
\hline Cpa_Ind & 10.61 & 10.00 & 5.07 & 1.00 & 25.00 \\
\hline Cpal_Ind & 8.11 & 7.00 & 4.91 & 1.00 & 24.00 \\
\hline Cpa2_Ind & 7.48 & 6.00 & 5.28 & 1.00 & 25.00 \\
\hline Big4 & .83 & 1.00 & .37 & .00 & 1.00 \\
\hline Market (\%) & .50 & .20 & .96 & .00 & 10.18 \\
\hline Spec & .02 & .00 & .13 & .00 & 1.00 \\
\hline Punish & .10 & .00 & .30 & .00 & 1.00 \\
\hline$C S R$ & .12 & .00 & .32 & .00 & 1.00 \\
\hline$R \& D(\%)$ & 4.22 & 1.25 & 21.27 & .00 & 997.30 \\
\hline Bate & .91 & .95 & .31 & -.81 & 1.78 \\
\hline Crisis & .02 & .00 & .15 & .00 & 1.00 \\
\hline Zscore & .34 & .00 & .47 & .00 & 1.00 \\
\hline Loss & .35 & .00 & .48 & .00 & 1.00 \\
\hline Size & 6.62 & 6.51 & .68 & 4.51 & 9.67 \\
\hline
\end{tabular}

Note. Obs.=3,621.

Variable Definitions: $D \& O=1$ if the company had D\&O insurance, 0 otherwise; Ins_Amt $=$ natural logarithm of the insured amount; Opion_GC=1 if the auditor issue going-concern opinion, 0 otherwise; Cpal_Age=years of leading auditor's seniority practice since 1983; Cpa1_Ind = years of leading auditor's industry experience since 1983;CPa2_Age =years of concurring auditor's seniority practice since 1983; Cpa2_Ind = years of concurring auditor's industry experience since 1983; Big4=1 if the company was audited by Big 4 firm, 0 otherwise; Market=the average market share of the auditors; $S p e c=1$ if the company was audited by an industry specialist, 0 otherwise; Punish=1 if the auditor had been punished by the authorities since 1998, 0 otherwise; $C S R=1$ if a company had experienced corporate social responsibility events in previous two years, 0 otherwise; $R \& D=$ the expenditure on research and development costs ratio; Bate=systematic risk, using the firm's market beta which is calculated over 12 months ending with the fiscal year end; Crisis $=1$ if the company had experienced a financial crisis event, 0 otherwise; Zscore $=1$ if the Altman $\mathrm{Z}$ score is less than 1.81, 0 otherwise; Loss $=1$ if a company reported a net loss in previous year, 0 otherwise; Size $=$ the company scale, natural logarithm of total assets.

\subsection{T Test of Insured and Uninsured Companies}

Core (2000) pointed out that a company's litigation risk is related to the quality of its governance, which ultimately affects the decision to purchase D\&O insurance. Alles, Datar, and Friedland (2006) argued that governance-linked $\mathrm{D} \& \mathrm{O}$ insurance is used for market-based governance, with process-based coverage providing the tools for superior governance risk management with the motivation for directors to exercise their fiduciary responsibilities. This study examined the mean of insured and uninsured companies to identify any differences in corporate governance characteristics. We compared ownership structure (i.e., the shares held by directors and supervisors, and shares held by institutional investors) and the management on corporate responsibility awareness (i.e., director and supervisors' shareholding pledge ratio, whether director and supervisors' holdings 
were below the statutory percentage, the manager's internalization, whether a manager was a concurrent board chairperson and CEO (chief executive officer), and the CEO and CFO (chief finance officer) turnover for the previous 3 years).

The results shown in Table 3 indicate that the shareholding of director and supervisor was lower and the proportion of institutional shareholders was higher among insured companies compared with uninsured companies. This indicates that insured companies have effective supervising mechanisms. However, the shareholding pledges and insufficient shareholding by directors and supervisors were more severe for companies with D\&O insurance than they were for those without D\&O insurance. Furthermore, the CEO and CFO turnover rates were higher among insured companies because the corporate governance of the insured companies was weaker than that of the uninsured companies. However, the insured companies compensated for their weaknesses through external monitoring mechanisms such as higher institutional shareholding and appointing Big 4 firms, and industry specialists to audit their financial statements.

Table 3. Difference test of with and without D\&O insurance

\begin{tabular}{|c|c|c|c|c|c|c|}
\hline & All Obs. & $\mathrm{D} \& \mathrm{O}$ insurer & Non- D\&O insurer & \multicolumn{3}{|c|}{$t$-test } \\
\hline & mean & mean & mean & $t$-value & $p$-value & \\
\hline \multicolumn{7}{|c|}{ Corporate governance } \\
\hline Dshare(\%) & 19.67 & 21.70 & 24.50 & -5.590 & $.000^{*}$ & *** \\
\hline Ishare(\%) & 7.77 & 9.70 & 5.80 & 9.460 & $.000^{*}$ & $* * *$ \\
\hline Pledge (\%) & 9.24 & 9.90 & 8.60 & 2.195 & $.028^{*}$ & $* *$ \\
\hline Insufy & .06 & .09 & .03 & 7.672 & $.000^{*}$ & *** \\
\hline MgInsid & .44 & .38 & .49 & -6.663 & $.000^{*}$ & *** \\
\hline Concure & .29 & .28 & .30 & -1.491 & .136 & \\
\hline CEO & .52 & .59 & .45 & 5.289 & $.000^{*}$ & *** \\
\hline$C F O$ & .58 & .66 & .51 & 4.755 & $.000^{*}$ & *** \\
\hline \multicolumn{7}{|c|}{ Auditor characteristics } \\
\hline Cpa_Age & 15.56 & 15.43 & 15.70 & -1.459 & .145 & \\
\hline Cpal_Age & 11.86 & 11.42 & 12.32 & -4.569 & $.000^{*}$ & $* * *$ \\
\hline Cpa2_Age & 11.88 & 12.22 & 11.52 & 3.308 & $.001^{*}$ & $* * *$ \\
\hline Cpa_Ind & 10.61 & 10.47 & 10.75 & -1.672 & $.095^{*}$ & * \\
\hline Cpal_Ind & 8.11 & 7.74 & 8.51 & -4.695 & $.000^{*}$ & $* * *$ \\
\hline Cpa2_Ind & 7.48 & 7.71 & 7.24 & 2.694 & $.007^{*}$ & *** \\
\hline Big4 & .83 & .89 & .78 & 8.951 & $.000^{*}$ & $* * *$ \\
\hline Market (\%) & .50 & .60 & .40 & 6.041 & $.000^{*}$ & *** \\
\hline Spec & .02 & .02 & .01 & 2.000 & $.046^{*}$ & $* *$ \\
\hline Punish & .10 & .10 & .10 & .079 & .937 & \\
\hline CSR & .12 & .13 & .10 & 2.356 & $.019^{*}$ & $* *$ \\
\hline$R \& D(\%)$ & 4.22 & 5.80 & 2.60 & 4.575 & $.000^{*}$ & $* * *$ \\
\hline Bate & .91 & .95 & .85 & 10.086 & $.000^{*}$ & *** \\
\hline Crisis & .02 & .02 & .02 & .258 & .796 & \\
\hline Zscore & .34 & .30 & .37 & -4.434 & $.000^{*}$ & $* * *$ \\
\hline Loss & .35 & .33 & .37 & -1.921 & $.055^{*}$ & $*$ \\
\hline Size & 6.62 & 6.69 & 6.54 & 6.850 & $.000^{*}$ & $* * *$ \\
\hline Obs. & 3,621 & 1,865 & 1,756 & & & \\
\hline
\end{tabular}

Note. Variable Definitions: Dshare=the ratio of shares held by directors and supervisors; Ishare=the ratio of shares held by institutional investors; Pledge=the ratio of pledged shares held by directors and supervisors; Insufy $=1$ if the shares held by directors and supervisors below the statutory percentage, 0 otherwise; $M g I n s i d=1$ if the manager internalization, 0 otherwise; Concure $=1$ if the manager was a concurrent board chairperson and the CEO, 0 otherwise; $C E O=$ the times of change in previous 3 years of the CEO; $C F O=$ the times of change in previous 3years of the CFO; Other variables are defined in Table 2.

Statistical significance: ${ }^{*} \mathrm{p}<.10 ; * * \mathrm{p}<.05 ; * * * \mathrm{p}<.01$ levels (two-tailed). 


\subsection{Correlation between Variables}

Table 4 shows the Pearson correlation coefficients for the discussed variables. Panel A shows the correlations of auditor characteristics, D\&O insurance, and going-concern opinions. The correlations for numerous independent variables are statistically significant, and the variance inflation factor (VIF) values shown in Panel B do not indicate the existence of a collinearity problem.

\subsection{Regression Analysis}

\subsubsection{Auditor Characteristics and D\&O Insurance}

In Table 5, Model 1 and 2 show the results of incorporating both auditors, whereas Models 3 and 4 show the results of the leading and concurring auditors (Note 6), respectively.

Table 4. Pearson correlation matrix

\begin{tabular}{|c|c|c|c|c|c|c|c|c|c|c|c|c|c|c|c|c|}
\hline \multicolumn{17}{|l|}{ Panel A } \\
\hline & Opin_GC & $D \& O$ & Cpa_Age & Cpa_Ind & Big 4 & Mark & & Spec & Punish & CSR & $R \& D$ & Bate & Crisis & Zscore & Loss & Size \\
\hline$O p i n \_G C$ & 1.00 & & & & & & & & & & & & & & & \\
\hline$D \& O$ & -.012 & 1.00 & & & & & & & & & & & & & & \\
\hline Cpa_Age & -.020 & -.024 & 1.00 & & & & & & & & & & & & & \\
\hline Cpa_Ind & $-.065^{* *}$ & -.028 & $.654^{* *}$ & 1.00 & & & & & & & & & & & & \\
\hline Big 4 & $-.139 * *$ & $.147^{* *}$ & $-.100 * *$ & $.047^{* *}$ & 1.00 & & & & & & & & & & & \\
\hline Market & -.028 & $.100^{* *}$ & $.084^{* *}$ & $.098 * *$ & $.204^{* *}$ & 1.00 & & & & & & & & & & \\
\hline Spec & -.020 & $.033^{*}$ & $.048^{* *}$ & -.022 & $.057^{* *}$ & .173 & $* *$ & 1.00 & & & & & & & & \\
\hline Punish & $.036^{*}$ & .001 & $.093^{* *}$ & $.033^{*}$ & $-.115^{* *}$ & -.033 & $*$ & -.028 & 1.00 & & & & & & & \\
\hline$C S R$ & $.105^{* *}$ & $.039^{*}$ & .010 & -.009 & -.008 & .040 & & $.069^{* *}$ & .012 & 1.00 & & & & & & \\
\hline$R \& D$ & .014 & $.076 * *$ & .022 & .015 & -.021 & .000 & & -.022 & $.063 * *$ & $.060^{*}$ & 1.00 & & & & & \\
\hline Bate & $-.090^{* *}$ & $.165^{* *}$ & .020 & $.079^{* *}$ & $.106^{* *}$ & .093 & $* *$ & .027 & -.015 & $.035^{*}$ & .012 & 1.00 & & & & \\
\hline Crisis & $.407^{* *}$ & .004 & $-.035 *$ & $-.064^{* *}$ & $-.143^{* *}$ & -.022 & & -.020 & $.052^{* *}$ & $.073^{*}$ & .020 & $-.111 *$ & 1.00 & & & \\
\hline Zscore & $.165^{* *}$ & $-.074^{* *}$ & .032 & .009 & $-.082 * *$ & -.002 & & .005 & .020 & $.186^{*}$ & -.013 & .016 & $.159^{* *}$ & 1.00 & & \\
\hline Loss & $.199^{* *}$ & -.032 & $-.036^{*}$ & $-.068^{* *}$ & $-.119^{* *}$ & -.092 & $* *$ & $-.076 * *$ & .014 & $.149^{*}$ & .080 & $-.034^{*}$ & $.184^{* *}$ & $.345^{* *}$ & 1.00 & \\
\hline Size & $-.092^{* *}$ & $.113^{* *}$ & $.086^{* *}$ & $.108^{* *}$ & $.157^{* * *}$ & .295 & $* *$ & $.250^{* *}$ & .002 & $.155^{*}$ & -.095 & $.340^{* *}$ & $-.131^{* *}$ & $.127^{* * *}$ & $-.189^{* *}$ & 1.00 \\
\hline \multicolumn{17}{|l|}{ Panel B } \\
\hline & $D \& O$ & Cpa_Age & Cpa_Ind & Big 4 & Mark & & Spec & $P u$ & ish & CSR & $R \& D$ & Bate & Crisis & Zscore & Loss & Size \\
\hline$D \& O$ & - & 1.839 & 1.821 & 1.130 & 1.15 & & 1.097 & & 28 & .084 & 1.027 & 1.154 & 1.089 & 1.229 & 1.258 & 1.457 \\
\hline Opin_GC & 1.072 & 1.839 & 1.825 & 1.147 & 1.15 & & 1.097 & & 28 & .085 & 1.033 & 1.174 & 1.091 & 1.238 & 1.259 & 1.461 \\
\hline
\end{tabular}

Table 5 shows that the coefficients for Cpa_Age are not significant in Models 1 and 2, although they are statistically significant and positive in Model 4 . These results imply that (a) the practice seniority of the leading auditor was unrelated to the $\mathrm{D} \& \mathrm{O}$ insurance of the client, and (b) the concurring auditor was relatively more careful about it. However, the coefficient for Cpal_Ind is statistically significant and negative $(\beta=-.028, p<.01)$ in Models 1 and 2, and the coefficient for Cpa2_Ind was significantly negative in Model 4. These results reflected the symbiotic system in the two-auditor environment in Taiwan, in which the client generally had a higher level of trust in the leading auditor. In practice, the companies frequently established relationships with the auditing firms because of the services offered by the leading auditor, indicating that the industry experience of auditors reduced the demand of insurance of clients.

Table 5. All sample-equation (1)

\begin{tabular}{|c|c|c|c|c|c|c|c|c|c|}
\hline & & \multicolumn{2}{|c|}{ Model 1} & \multicolumn{2}{|c|}{ Model 2} & \multicolumn{2}{|c|}{ Model 3} & \multicolumn{2}{|c|}{ Model 4} \\
\hline & & Coefficient & $P_{\text {_value }}$ & Coefficient & $P_{\text {_value }}$ & Coefficient & $P_{\text {_value }}$ & Coefficient & $P_{-}$value \\
\hline Cpa_Age & + & .009 & .300 & & & & & & \\
\hline Cpal_Age & + & & & .008 & .413 & .013 & .174 & & \\
\hline Cpa2_Age & + & & & .013 & .122 & & & .019 & $.018^{* *}$ \\
\hline Cpa_Ind & - & -.028 & $.003^{* * *}$ & & & & & & \\
\hline Cpal_Ind & - & & & -.038 & $.001^{* * *}$ & -.043 & $.000^{* * *}$ & & \\
\hline Cpa2_Ind & - & & & -.009 & .398 & & & -.017 & $.079^{*}$ \\
\hline Big4 & + & .624 & $.000^{* * *}$ & .588 & $.000^{* * *}$ & .556 & $.000^{* * *}$ & .632 & $.000^{* * * *}$ \\
\hline Market & + & 9.635 & $.021^{* * * *}$ & 8.439 & $.043^{* *}$ & 9.734 & $.020^{* *}$ & 9.047 & $.031^{* *}$ \\
\hline
\end{tabular}




\begin{tabular}{|c|c|c|c|c|c|c|c|c|c|}
\hline Spec & - & -.027 & .926 & -.034 & .908 & & & & \\
\hline Spec_1 & - & & & & & -.255 & .402 & & \\
\hline Spec_2 & - & & & & & & & -.350 & .255 \\
\hline Punish & + & .095 & .430 & .102 & .400 & & & & \\
\hline Punish_1 & + & & & & & -.142 & .204 & & \\
\hline Punish_2 & + & & & & & & & .273 & $.013^{* *}$ \\
\hline CSR & + & .217 & $.057^{*}$ & .218 & $.056^{*}$ & .220 & $.054^{*}$ & .219 & $.054^{*}$ \\
\hline$R \& D$ & + & 5.118 & $.000^{* * *}$ & 5.151 & $.000^{* * *}$ & 5.157 & $.000^{* * *}$ & 5.134 & $.000^{* * *}$ \\
\hline Bate & + & .827 & $.000^{* * * *}$ & .836 & $.000^{* * *}$ & .824 & $.000^{* * * *}$ & .819 & $.000^{* * * *}$ \\
\hline Crisis & + & .674 & $.006^{* * *}$ & .682 & $.005^{* * *}$ & .708 & $.004^{* * *}$ & .692 & $.005^{* * *}$ \\
\hline Zscore & + & -.410 & $.000^{* * *}$ & -.416 & $.000^{* * *}$ & -.415 & $.000^{* * *}$ & -.417 & $.000^{* * *}$ \\
\hline Loss & + & .014 & .862 & .009 & .916 & .002 & .976 & .025 & .764 \\
\hline Size & + & .312 & $.000^{* * *}$ & .308 & $.000^{* * *}$ & .320 & $.000^{* * *}$ & .309 & $.000^{* * *}$ \\
\hline \multicolumn{2}{|l|}{ Constant } & -3.262 & $.000^{* * *}$ & -3.230 & $.000^{* * *}$ & -3.188 & $.000^{* * *}$ & -3.495 & $.000^{* * *}$ \\
\hline \multicolumn{2}{|l|}{ Industry } & Included & & Included & & Included & & Included & \\
\hline \multicolumn{2}{|c|}{ Cox\& Snell $\mathrm{R}^{2}$} & .083 & & .087 & & .087 & & .084 & \\
\hline \multicolumn{2}{|c|}{ Nagelkerke $\mathrm{R}^{2}$} & .111 & & .116 & & .115 & & .112 & \\
\hline \multicolumn{2}{|l|}{ Obs. } & 3621 & & 3621 & & 3621 & & 3621 & \\
\hline
\end{tabular}

Note. All variables are defined in Table 2. Statistical significance: $* \mathrm{p}<.10 ; * * \mathrm{p}<.05 ; * * * \mathrm{p}<.01$ levels (two-tailed).

This finding is also reflected in the Spec variable. The coefficient for Spec was non-significant and negative for all of the models, implying that the D\&O coverage of the client was lower when the auditors were industry specialists. These results indicate that auditors with relatively more industry experience can indirectly reduce the insurance premiums of their clients; therefore, they can decrease the demand for D\&O insurance. In other word, for some companies, engaging specialist auditors may be a substitute governance mechanism for $\mathrm{D} \& \mathrm{O}$ insurance.

Moreover, the coefficients for Big 4 and Market were significant and positive in all of the models, indicating that audit firms with a greater market share and better reputations were more diligent in considering the risk diversification of $\mathrm{D} \& \mathrm{O}$ insurance. The monitoring by Big 4 can increase the number of companies that had D\&O insurance. In Model 1, the coefficient of Punish is positive, and the coefficient of Punish_cpa2 is statistically significant and positive in Model 4, indicating that the clients tended to have a higher D\&O coverage if the auditors had been punished by authorities. The risk factor variables (CSR, R\&D, Bate, and Crisis) were statistically significant and positive, and the coefficient of Zscore is significantly negative in all of the models, indicating that the demand for company D\&O insurance is increasing with the business risk company faced. Besides, for the effect of size on D\&O insurance, the results show that company is significantly positively associated with $\mathrm{D} \& \mathrm{O}$ insurance. Consistent with prior studies, we find that the demand for D\&O insurance is increasing with the size of company.

Furthermore, we tested the subsample of insured companies and used the insured amount (Ins_Amt) as a dependent variable. The results shown in Table 6 indicate that the practice seniority of auditors reduced the insurance cost and is negative with insured amount; however, auditors with comparatively greater industry experience, greater market share, better reputation (Big4), and those that had been punished by authorities made their clients had higher insured amount. The results of other explanatory variables are similar to the results as shown in Table 5. 
Table 6. Insured subsample-equation (2)

\begin{tabular}{|c|c|c|c|c|c|c|c|c|c|c|}
\hline \multirow[b]{3}{*}{ Cpa_Age } & \multirow[b]{3}{*}{+} & \multicolumn{3}{|c|}{ Model 1} & \multicolumn{2}{|c|}{ Model 2} & \multicolumn{2}{|c|}{ Model 3} & \multicolumn{2}{|c|}{ Model 4} \\
\hline & & \multirow{2}{*}{$\begin{array}{r}\text { Coefficient } \\
-.006\end{array}$} & \multicolumn{2}{|c|}{$P_{\text {_value }}$} & \multirow[t]{2}{*}{ Coefficient } & $P_{\text {_value }}$ & \multirow[t]{2}{*}{ Coefficient } & $P_{\text {_value }}$ & \multirow[t]{2}{*}{ Coefficient } & $P \_$value \\
\hline & & & .012 & ** & & & & & & \\
\hline Cpal_Age & + & & & & .000 & .929 & -.002 & .367 & & \\
\hline Cpa2_Age & + & & & & -.007 & $.001^{* * *}$ & & & -.007 & $.001^{* * * *}$ \\
\hline Cpa_Ind & - & .006 & .017 & ** & & & & & & \\
\hline Cpal_Ind & - & & & & -.003 & .309 & .000 & .945 & & \\
\hline Cpa2_Ind & - & & & & .010 & $.000^{* * *}$ & & & .009 & $.000^{* * * *}$ \\
\hline Big4 & + & .142 & .000 & ${ }^{* * *}$ & .141 & $.000^{* * *}$ & .149 & $.000^{* * *}$ & .142 & $.000^{* * *}$ \\
\hline Market & + & 2.501 & .004 & ${ }^{* * *}$ & 2.506 & $.004^{* * *}$ & 2.346 & $.007^{* * * *}$ & 2.456 & $.005^{* * * * *}$ \\
\hline Spec & - & .027 & .691 & & .044 & .523 & & & & \\
\hline Spec_1 & - & & & & & & -.004 & .961 & & \\
\hline Spec_2 & - & & & & & & & & .074 & .346 \\
\hline Punish & + & .078 & .014 & ${ }^{* *}$ & .077 & $.014^{* *}$ & & & & \\
\hline Punish_1 & + & & & & & & .031 & .348 & & \\
\hline Punish_2 & + & & & & & & & & .077 & $.004^{* * * *}$ \\
\hline$C S R$ & + & -.048 & .095 & * & -.050 & .081 & -.052 & .074 & -.050 & .081 \\
\hline$R \& D$ & + & .072 & .027 & ** & .069 & $.034^{* *}$ & .076 & $.020^{* *}$ & .074 & $.021^{* *}$ \\
\hline Bate & + & .033 & .340 & & .030 & .377 & .037 & .282 & .029 & .393 \\
\hline Crisis & + & .270 & .000 & ${ }^{* * *}$ & .260 & $.000^{* * *}$ & .268 & $.000^{* * *}$ & .268 & $.000^{* * * *}$ \\
\hline Zscore & + & -.040 & .076 & * & -.037 & $.100^{*}$ & -.041 & .072 & -.039 & .087 \\
\hline Loss & + & .031 & .157 & & .029 & .186 & .029 & .187 & .030 & .179 \\
\hline Size & + & .312 & .000 & ${ }^{* * *}$ & .313 & $.000^{* * *}$ & .318 & $.000^{* * *}$ & .312 & $.000^{* * *}$ \\
\hline Constant & & 2.962 & .000 & ${ }^{* * *}$ & 2.971 & $.000^{* * *}$ & 2.928 & $.000^{* * *}$ & 2.956 & $.000^{* * *}$ \\
\hline Industry & & & cluded & & & cluded & & cluded & & cluded \\
\hline Adjusted $\mathrm{R}$ & & .285 & & & .288 & & .281 & & .289 & \\
\hline Obs. & & 1865 & & & 1865 & & 1865 & & 1865 & \\
\hline
\end{tabular}

Note. All variables are defined in Table 2. Statistical significance: $* \mathrm{p}<.10 ; * * \mathrm{p}<.05 ; * * * \mathrm{p}<.01$ levels (two-tailed).

\subsubsection{Auditor Characteristics, D\&O Insurance, and Going-Concern Opinions}

We included the independent variable $D \& O$ in Equation (5) and variable Ins_Amt in Equation (6) to test the relationships among auditor characteristics, D\&O insurance, and going-concern opinions. Since the going-concern issue may mainly considered in companies with high financial distress probabilities, we use only companies with Altman $\mathrm{Z}$ scores less 1.81 to be the sample companies in the section. In addition, as mentioned before, to control for the possible self-selection problems, the Heckman two-stage (Heckman, 1979) regression is used to discuss in this study. Panel A of Table 7 presented the first stage regression results, and the results show that $R \& D$, Bate and Crisis are significantly positively associated with D\&O insurance. In Panel B of Table 7, which represents the second stage results after controlling possible self-selection problem, we find that $C p a \_$Ind and Big4 are significantly negatively associated with the issuing of going concern opinion. However, while Spec is negatively associated with the issuing of going concern opinion as well, the correlation is not significant. In other words, compared to auditors' industry experience and audit firm size, auditor specialization possess less influence on issuing going concern opinion of auditors. In addition, for adding the interaction items $B i g 4 \times D \& O$, Spec $\times D \& O$, and Big $4 \times$ Spec $\times D \& O$, we find that among the three interaction variables, only $B i g 4 \times D \& O$ is significantly negatively associated with the issuing of going concern opinion. It is consistent with our expectations that since Big 4 auditors have higher cost of audit failure, and D\&O insurance may partially cover the litigation risk and loss of audit failure, the effects of D\&O insurance on auditors' intension of issuing going-concern opinions are more significant for Big 4 auditors. 
Table 7. Two steps regression of going concern opinion with $D \& O$ variable

\begin{tabular}{|c|c|c|c|c|c|c|c|c|c|c|c|c|c|c|c|c|}
\hline \multicolumn{17}{|c|}{ (2) } \\
\hline \multirow{2}{*}{ Step 1} & \multicolumn{6}{|c|}{ Model 1: All Sample ---Equation (3) } & \multirow{2}{*}{ Step 1} & \multicolumn{9}{|c|}{ Model 2: Altman Z score less than 1.81 subsample --Equation (3) } \\
\hline & \multirow{2}{*}{$\begin{array}{l}\text { sign } \\
+\end{array}$} & \multicolumn{2}{|c|}{ Coefficient } & \multicolumn{2}{|c|}{$P$ _value } & \multirow{2}{*}{$\begin{array}{r}\text { VIF } \\
1.051\end{array}$} & & & \multirow{2}{*}{$\begin{array}{l}\text { sign } \\
++\end{array}$} & \multirow{2}{*}{\multicolumn{2}{|c|}{$\begin{array}{r}\text { Coefficient } \\
061\end{array}$}} & \multicolumn{2}{|c|}{$P \_$value } & \multicolumn{2}{|l|}{ VIF } \\
\hline CSR & & & .069 & .008 & *** & & & CS & & & & & .083 & $3^{*}$ & \multicolumn{2}{|l|}{1.016} \\
\hline$R \& D$ & + & & .166 & .000 & **** & 1.012 & & \multicolumn{2}{|c|}{$R \& D$} & + & \multicolumn{2}{|l|}{$\begin{array}{l}.061 \\
.402\end{array}$} & .000 & 0 *** & \multicolumn{2}{|l|}{1.018} \\
\hline Bate & + & & .274 & .000 & *** & 1.016 & & \multicolumn{2}{|c|}{ Bate } & + & \multicolumn{2}{|l|}{.236} & .000 & **** & \multicolumn{2}{|l|}{1.041} \\
\hline Crisis & + & & .113 & .040 & $* *$ & 1.061 & & \multicolumn{2}{|c|}{ Crisis } & + & \multicolumn{2}{|l|}{.123} & .047 & 7 ** & 1.060 & \\
\hline Zscore & + & & -.088 & .000 & *** & 1.175 & & \multicolumn{2}{|c|}{ Loss } & + & \multicolumn{2}{|c|}{.011} & .703 & & 1.064 & \\
\hline Loss & + & & -.017 & .365 & & 1.175 & & & & & & & & & & \\
\hline Adjusted $\mathrm{R}^{2}$ & & & .040 & & & & & & justed $\mathrm{R}^{2}$ & & .037 & & & & & \\
\hline Obs. & & & 3621 & & & & & $\mathrm{Ol}$ & & & 1223 & & & & & \\
\hline Panel B & & & & & & & & & & & & & & & & \\
\hline & & & All sample ---Eq & ation ( & & & & & Altman Z sco & re less than & 81 subsample & --Equation & & & & \\
\hline Step 2 & & & Mode & & & Model & & & Model & & Mode & & & Model & & \\
\hline & & & Coefficient & P_val & & Coefficient & P_value & & Coefficient & P_value & Coefficient & P_value & & efficient & P_value & \\
\hline Cpa_Age & & $+/-$ & .008 & .733 & & .036 & .194 & & .032 & .257 & .036 & .194 & & .036 & .194 & \\
\hline Cpa_Ind & & $+/-$ & -.071 & .015 & & -.080 & $.016^{\circ}$ & - & -.072 & $.030^{\circ}{ }^{\circ}$ & -.080 & $.016^{*}$ & & -.080 & .016 & ** \\
\hline Big4 & & $+/-$ & -1.402 & .000 & & -1.133 & $.000^{\circ}$ & $\cdots$ & -.763 & $.039^{*}$ & -1.133 & $.000 \cdots$ & & -1.133 & .000 & $\cdots$ \\
\hline Market & & $+/$ & 14.628 & .286 & & 9.184 & .609 & & 9.235 & .610 & 9.184 & .609 & & 9.184 & .609 & \\
\hline Spec & & $+/$ & -16.049 & .997 & & -16.739 & .998 & & -16.602 & .998 & -16.877 & .999 & & -16.877 & .999 & \\
\hline Punish & & $+/-$ & .362 & .257 & & .486 & .171 & & .491 & .169 & .486 & .171 & & .486 & .171 & \\
\hline Size & & $+/-$ & -.826 & .000 & & -.836 & $.000^{\circ}$ & $\cdots$ & -.849 & $.000^{\cdots}$ & -.836 & $.000 \cdots$ & & -.836 & .000 & $\cdots$ \\
\hline$D \& O$ & & + & -1.592 & .130 & & 3.165 & $.001^{\circ}$ & $\cdots$ & 3.727 & $.000^{\cdots}$ & 3.165 & $.001 \cdots$ & & 3.165 & .001 & $\cdots$ \\
\hline Mills & & + & 1.788 & .095 & & -3.023 & .002 & $\cdots$ & -3.144 & $.001 \cdots$ & -3.023 & $.002 \cdots$ & & -3.023 & .002 & $\cdots$ \\
\hline$B i g 4^{*} D \& O \_d$ & & & & & & & & & -.843 & $.100^{\circ}$ & & & & & & \\
\hline $\operatorname{Spec}^{*} D \& O \_d$ & & & & & & & & & & & .173 & 1.000 & & & & \\
\hline$B i g 4^{*} S p e c^{*} D \& O \_d$ & & & & & & & & & & & & & & .173 & 1.000 & \\
\hline Constant & & & 3.774 & .005 & 5 & 1.992 & .127 & & 1.827 & .169 & 1.992 & .127 & & 1.992 & .127 & \\
\hline Industry & & & Included & & & Included & & & Included & & Included & & & Included & & \\
\hline Cox \& Snell $\mathrm{R}^{2}$ & & & .024 & & & .062 & & & .064 & & .062 & & & .062 & & \\
\hline Nagelkerke $\mathrm{R}^{2}$ & & & .124 & & & .173 & & & .178 & & .173 & & & .173 & & \\
\hline Obs. & & & 3621 & & & 1223 & & & 1223 & & 1223 & & & 1223 & & \\
\hline
\end{tabular}

Table 8 presents the results for insured companies with high financial distress probabilities (companies with Altman Z scores less 1.81). For including insurance amount (Ins_Amt) in the regression, Panel A of Table 8 shows that Zscore is significantly positively associated with Ins_Amt, which demonstrate that the amount of company D\&O insurance is increasing with its risk of financial distress. Similar as the results presented of Table 7, the results in Panel B of Table 8 shows that Cpa_Ind, Big4, and Spec is negatively associated with the issuing of going concern opinion, and the coefficient is significant for Big4 only. For the interaction items, the results in Panel B of Table 8 also only Big $4 \times$ Ins_Amt is significantly negatively associated with the issuing of going concern opinion. The results of Table 8 show that the findings of two set of sample are consistent.

Table 8. Two steps regression of going concern opinion with Ins_Amt variable

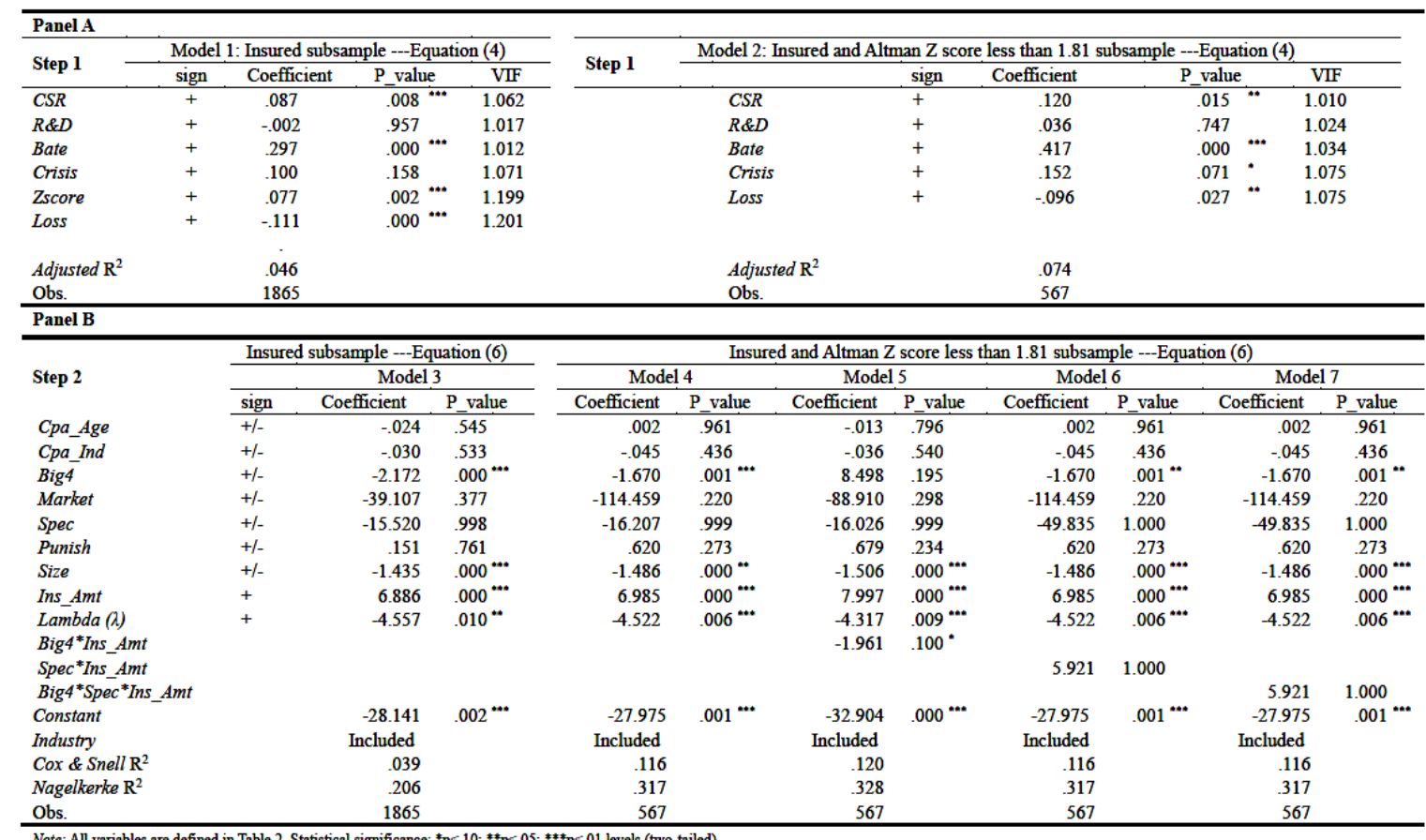




\subsection{Sensitivity Analysis}

\subsubsection{Incorporate the Corporate Governance Variables}

For considering the possible effects of corporate governance factors on D\&O insurance and auditors' intention of issuing going concern opinions, besides to business and financial risk of companies, we include corporate governance variables to explore the analyses further. The results show that, besides affecting business risk, the quality of corporate governance does have impact auditors' intention of issuing going-concern opinions. The results show that, among corporate governance variables (Note 7), the pledge ratio of directors and supervisors shareholding, and the frequencies of CEO and CFO changes, are significantly positively associated with D\&O insurance. For the main variables, the results are similar to those shown in Tables 5 to 8 .

\subsubsection{Deleting the Financial Industry and Including the Credit Rating Indicator}

Financial services industries, such as banking, insurance, securities, and futures, are typically involved in leveraging high-risk operations; therefore, these industries tend to have insurance coverage (> 70\%, Table 1). However, the TEJ database does not include credit ratings for these industries. We removed 132 observations for companies in financial industries, and 10 observations that lacked credit rating data. Subsequently, we incorporated the credit rating indicator (TCRI) variable into Equations. This credit rating indicator was based on a scale from 1 to 10 , where a lower score indicates that a company has a higher credit rating. The results of the main independent variables were similar to those shown in Tables 5 to Table 8 .

\section{Conclusion}

This study examined the relationships between auditor characteristics and D\&O insurance, and assessed whether such insurance has an effect on audit opinions. For the insured decision, the results show that clients of auditors with greater market shares, belongs to Big 4, and those that had been punished had higher D\&O insurance coverage. For the effects of audit opinion, the results show that the industry-specific experience of auditors and audit firm size are significantly negatively associated with the issuing of going-concern opinion. It is consistent with our expectations that since Big 4 auditors may share more litigation risk and possess more loss coverage of audit failure of $\mathrm{D} \& \mathrm{O}$ insurance, the effects of $\mathrm{D} \& \mathrm{O}$ insurance on auditors' intention of issuing going-concern opinions are more significant for Big 4 auditors.

Furthermore, the results of this study also show that, compared to those with D\&O insurance, companies without D\&O insurance had better corporate governance mechanisms. We infer the results to that, in comparison with companies with better corporate governance, companies with poorer corporate governance may have higher demand for $\mathrm{D} \& \mathrm{O}$ insurance and higher quality auditors, since having such allows them to gain a positive response from capital market. Therefore, there is a complementary relationship between purchasing D\&O insurance, strengthening corporate governance mechanisms, and engaging with high-quality auditors based on the cost control for overall corporate governance investment.

This study may have following limitations. First, due to the limitation of audit fee data, we are not able to directly test the insurance substitute effects by examining the association between audit fee and the coverage of $\mathrm{D} \& \mathrm{O}$ insurance. This is the main limitation of this study. In addition, while premiums of insurance fee may influence the decision of $\mathrm{D} \& \mathrm{O}$ insurance as well, it should be considered for the purchase of D\&O insurance; however, while not required to be disclosed in Taiwan, we are not able to include it in the analyses. Furthermore, since the sample distribution reveals that the financial services industry has the highest insurance rate among all industries; this observation maybe worthy of further discussion and examination.

\section{References}

Abbott, L. J., \& Parker, S. (2000). Auditor selection and audit committee characteristics. Auditing: A Journal of Practice \& Theory, 19, 47-66. http://dx.doi.org/ 10.2308/aud.2000.19.2.47

Alles, M., Datar, S., \& Friedland, J. (2006). Governance-linked D\&O: Market-based governance leveraging $\mathrm{D} \& \mathrm{O}$ insurance to drive corporate governance. International Journal of Disclosure and Governance, 3, 84-98. http://dx.doi.org/ 10.1057/palgrave.jdg.2040068

Ashbaugh-Skaife, H., Collins, D., \& Kinney, W. (2007). The discovery and reporting of internal control deficiencies prior to SOX-mandated audits. Journal of Accounting and Economics, 44, 166-192. http://dx.doi.org/ 10.1016/j.jacceco.2006.10.001

Asthana, S. C., Balsam, S., \& Krishnan, J. (2010). Corporate governance, audit firm reputation, auditor switches, and client stock price. International Journal of Auditing, 14, 274-293. http://dx.doi.org/10.1016/j.jacceco.2006.10.001 
Barrese, J., \& Scordis, N. (2006). Managerial bias in corporate governance and the effect of D\&O Insurance: A literature review and synthesis. International Journal of Disclosure and Governance, 3, 185-196. http://dx.doi.org/ 10.1057/palgrave.jdg.2040078

Becker, C. L., DeFond, M. J., Jiambalvo, M. L., \& Subramanyam, J. J. (1998). The effect of auditor quality on earning management. Contemporary Accounting Research, 15, 1-24. http://dx.doi.org/10.1111/j.1911-3846.1998.tb00547.x

Blacconiere, W. G., \& DeFond, M. L. (1997). An investigation of independent audit opinions and subsequent independent auditor litigation of publicly-traded failed savings and loans. Journal of Accounting and Public Policy, 16, 415-454. http://dx.doi.org/ 10.1016/S0278-4254(96)00042-7

Boyer, M. (2003). Is the demand for corporate insurance a habit? Evidence from directors and officers insurance. CIRANO discussion paper, Montreal, Canada. http://dx.doi.org/ 10.1016/j.jcorpfin.2011.12.005

Cao, Z., \& Narayanamoorthy, G. S. (2014). Accounting and litigation risk: Evidence from directors' and officers' insurance pricing. Review of Accounting Studies, 19, 1-42. http://dx.doi.org/ 10.1007/s11142-013-9249-4

Carcello, J. V., \& Neal, T. L. (2000). Audit committee composition and auditor reporting. The Accounting Review, 75, 453-467. http://dx.doi.org/ 10.2308/accr.2000.75.4.453

Carcello, J. V., \& Neal, T. L. (2003). Audit committee characteristics and auditor dismissals following "new" going-concern reports. The Accounting Review, 78, 95-117. http://dx.doi.org/ 10.2308/accr.2003.78.1.95

Carcello, J. V., \& Palmrose, Z. (1994). Auditor litigation and modified reporting on bankrupt clients. Journal of Accounting Research, 32, 1-30. http://dx.doi.org/ 10.2307/2491437

Casterella, J. R., Francis, J. R., Lewis, B. L., \& Walker, P. L. (2004). Auditor industry specialization, client bargaining power, and audit pricing. Auditing: A Journal of Practice and Theory, 23, 123-140. http://dx.doi.org/ 10.2308/aud.2004.23.1.123

Casterella, J. R., Jensen, K. L., \& Knechel, W. R. (2010). Litigation risk and audit firm characteristic. Auditing: A Journal of Practice and Theory, 29, 71-82. http://dx.doi.org/ 10.2308/aud.2010.29.2.71

Chamlers, J. M. R., Dann, L. Y., \& Harford, J. (2002). Managerial opportunism? Evidence from directors' and officers' insurance purchases. Journal of Finance, 57, 609-636. http://dx.doi.org/ 10.1111/1540-6261.00436

Chen, C. (2013). Invisible gatekeeper? Director \& officer insurance in corporate governance: An empirical legal study of Taiwan. UMI Dissertations Publishing, University of Illinois at Urbana-Champaign. http://dx.doi.org/10.2139/ssrn.2056623

Chen, T. J., \& Pang, C. H. (2008). An analysis of determinants of the corporate demand for directors' and officers' liability insurance. National Taiwan University Management Review, 18, 171-196. http://dx.doi.org/10.6226/NTURM2008.18.2.171

Chen, T., \& Li, S. (2010). Directors' \& officers' insurance, corporate governance and firm performance. International Journal of Disclosure and Governance, 7, 244-261. http://dx.doi.org/ 10.1057/jdg.2010.9

Chung, H. H., \& Wynn, J. P. (2008). Managerial legal liability coverage and earnings conservatism. Journal of Accounting and Economics, 46, 135-153. http://dx.doi.org/ 10.1016/j.jacceco.2008.03.002

Core, J. E. (1997). On the corporate demand for director' and officers' insurance. Journal of Risk and Insurance, 64, 63-87. http://dx.doi.org/ 10.2307/253912

Core, J. E. (2000). The directors' and officers' insurance premium: An outside assessment of the quality of corporate governance. Journal of Law, Economics \& Organization, 16, 449-477. http://dx.doi.org/10.1093/jleo/16.2.449

DeAngelo, L. (1981a). Auditor independence, low balling and disclosure regulation. Journal of Accounting and Economics, 3, 113-127. http://dx.doi.org/ 10.1016/0165-4101(81)90009-4

DeAngelo, L. (1981b). Auditor size and audit quality. Journal of Accounting and Economics, 3, 183-199. http://dx.doi.org/ 10.1016/0165-4101(81)90002-1

DeFond, M., \& Hung, M. (2004). Investor protection and corporate governance: Evidence from worldwide CEO $\begin{array}{lllll}\text { turnover. Journal of Accounting } & \text { Research, 42, }\end{array}$ http://dx.doi.org/10.1111/j.1475-679X.2004.00138.x

Dye, R. A. (1993). Auditing standards, legal liability, and auditor wealth. Journal of Political Economy, 101, 887-914. http://dx.doi.org/ 10.1086/261908 
Ge, W., \& McVay, S. (2005). The disclosure of material weaknesses in internal control after the Sarbanes-Oxley Act. Accounting Horizons, 19, 137-158. http://dx.doi.org/ 10.2308/acch.2005.19.3.137

Geiger, M. A., \& Raghunandan, K. (2002). Auditor tenure and audit reporting failures. Auditing: A Journal of Practice \& Theory, 21, 67-78. http://dx.doi.org/ 10.2308/aud.2002.21.1.67

Goodwin, J., \& Seow, J. L. (2002). The influence of corporate governance mechanisms on the quality of financial reporting and auditing: Perceptions of auditors and directors in Singapore. Accounting and Finance, 42, 195-224. http://dx.doi.org/ 10.1111/1467-629X.t01-1-00074

Heckman, J. J. (1979). Sample selection bias as a specification error. Econometrica, 47, 153-162. http://dx.doi.org/ 10.2307/1912352

Holderness, O. G. (1990). Liability insurers as corporate monitors. International Review of Law and Economics, 10, 115-129. http://dx.doi.org/ 10.1016/0144-8188(90)90018-O

Hoyt, R. E., \& Khang, H. (2000). On the demand for corporate property insurance. Journal of Risk and Insurance, 67, 91-107. http://dx.doi.org/ 10.2307/253678

Huang, H., Liu, L., Raghunandan, K., \& Rama, D. V. (2007). Auditor industry specialization, client bargaining power, and audit fees: further evidence. Auditing: A Journal of Practice \& Theory, 26, 147-158. http://dx.doi.org/ 10.2308/aud.2007.26.1.147

Jackson, A. B., Moldrich, M., \& Roebuck, P. (2008). Mandatory audit firm rotation and audit quality. Managerial Auditing Journal, 23, 420-437. http://dx.doi.org/ 10.1108/02686900810875271

Jensen, M. C., \& Meckling, W. H. (1976). Theory of the firm: Manager behavior, agency costs and ownership structure. Journal of Financial Economics, 3, 305-360. http://dx.doi.org/ 10.1016/0304-405X (76)90026-X

Johnstone, K. M., \& Bedard, J. C. (2004). Audit firm portfolio management decision. Journal of Accounting Research, 42, 659-690. http://dx.doi.org/ 10.1111/j.1475-679X.2004.00153.x

Khurana, I. K., \& Raman, K. K. (2004). Litigation risk and the financial reporting credibility of big 4 versus non-big 4 audits: Evidence from Anglo-American countries. The Accounting Review, 79, 473-495. http://dx.doi.org/ 10.2308/accr.2004.79.2.473

Krishnan, G. V. (2003). Does big 6 auditor industry expertise constrain earnings management? Accounting Horizons, 17, 1-16. http://dx.doi.org/ 10.2308/acch.2003.17.s-1.1

Lennox, C. (1999). Are large auditors more accurate than small auditors? Accounting and Business Research, 29, 217-227. http://dx.doi.org/ 10.1080/00014788.1999.9729582

Lin, C., Officer, M. S., \& Zou, H. (2011). Directors' and officers' liability insurance and acquisition outcomes. Journal of Financial Economics, 102, 507-525. http://dx.doi.org/ 10.1016/j.jfineco.2011.08.004

Louis, H. (2005). Acquirers' abnormal returns and the Non-Big 4 auditor clientele effect. Journal of Accounting \& Economics, 40, 75-99. http://dx.doi.org/ 10.1016/j.jacceco.2005.03.001

Mayers, D., \& Smith, C. W. (1990). On the corporate demand for insurance: Evidence from the reinsurance market. Journal of Business, 63, 19-40. http://dx.doi.org/ 10.1086/296481

McKeown, J. C., Mutchler, J. F., \& Hopwood, W. (1991). Towards an explanation of auditor failure to modify the audit opinions of bankrupt companies. Auditing: A Journal of Practice \& Theory, 10, 1-13.

O'Sullivan, N. (2002). The demand for directors' and officers' insurance by large UK companies. European Management Journal, October, 574-583. http://dx.doi.org/ 10.1016/S0263-2373(02)00096-8

Redington, W. (2005). D\&O underwriting implications of Sarbanes-Oxley. International Journal of Disclosure and Governance, June, 151-158. http://dx.doi.org/ 10.1057/palgrave.jdg.2040049

Reynolds, J. K., Deis, D. R., \& Francis, J. R. (2004). Professional service fees and auditor objectivity. Auditing: A Journal of Practice \& Theory, 23, 29-52. http://dx.doi.org/ 10.2308/aud.2004.23.1.29

Rose-Green. E., Huang, H. W., \& Lee, C. C. (2011). The association between auditor industry specialization and firms' disclosure of internal control weaknesses. International Journal of Auditing, 15, 204-216. http://dx.doi.org/ 10.2139/ssrn.1599748

Seetharaman, A., Gul, E., \& Lynn, S. (2002). Litigation risk and audit fees: Evidence from UK firms cross listed on US markets. Journal of Accounting and Economics, 33, 91-115. http://dx.doi.org/10.1016/S0165-4101(01)00046-5 
Wen, C. C. (2011). Investigating the association between the amount of directors' and officers' liability insurance and accounting earnings quality. Unpublished dissertation, University of Taiwan, Taiwan. http://dx.doi.org/ 10.6226/NTURM2013.APR.R13004

\section{Notes}

Note 1. Chalmers et al. (2002) find that managers may purchase D\&O insurance when they sell over-valued equity to shareholders to reduce the liability costs associated with potential future litigation.

Note 2. In Taiwan, the standard governance structure of corporations includes a two-tier (dual board) structure that comprises the board of supervisors and the board of directors. Shareholders, as the corporation's owners, elect directors and supervisors at annual shareholder meetings.

Note 3. Because the data was not available in the TEJ database before 1983, we calculated their personal history since 1983.

Note 4. Because a list of punished auditors was not available until 1998, we set this variable at 1 if either the lead or concurrent auditor had been punished since 1998 .

Note 5. The negative social responsibility events include labor disputes, violations of information disclosure obligations, and subjections to penalties by the authorities.

Note 6. Since 1983, Taiwanese public companies must be concurrently audited by two auditors and the requirement for dual signatures raises a measurement issue concerning the identification of individual auditors. Because of the knowledge spill-over effect, whichever partner is the specialist can share his or her knowledge with a whole audit team; therefore, as long as one of a company's leading or concurring auditors is a specialist in an industry, the company will be classified into a specialist group for auditor industry specialization. However, for the experience and auditor sanction, these leading and concurring auditors could be considered separately. For this reason, we examine leading and concurring auditors for individual auditors' experience and sanction.

Note 7. The corporate governance variables that used in the analysis include: among directors' and supervisors holdings (Dshare), the shares held by directors and supervisors, institutional holdings (Ishare), the pledge ratio of director and supervisors (Pledge), shareholding' the manager's internalization (MgInsid), duality of CEO (Concure), and turnover of $\mathrm{CEO}$ and $\mathrm{CFO}(\mathrm{CEO}$ and $\mathrm{CFO})$, the pledge ratio of director and supervisors.

\section{Copyrights}

Copyright for this article is retained by the author(s), with first publication rights granted to the journal.

This is an open-access article distributed under the terms and conditions of the Creative Commons Attribution license (http://creativecommons.org/licenses/by/3.0/). 